\title{
Phosphorylation of small GTPase Rab proteins from Bombyx mori (Lepidoptera: Bombycidae)
}

\author{
Tomohide UNO $^{1}$, Keisuke HATA $^{1}$, Le Thi DIEU TRANG ${ }^{2}$, Susumu HIRAGAKI ${ }^{2}$, Takuya NAKADA ${ }^{1}$, \\ MasAhiko NAKAMURA ${ }^{3}$, YUichi UNO ${ }^{4}$, Hiroshi YAMAGATA ${ }^{1}$, Kengo KANAMARU $^{1}$, MaKio TAKEDA ${ }^{2}$ \\ and MAMORU MATSUBARA ${ }^{3}$ \\ ${ }^{1}$ Laboratory of Biological Chemistry, Department of Biofunctional Chemistry, Faculty of Agriculture, Kobe University, \\ Nada-ku Hyogo 657-8501, Japan; e-mail: unotom@kobe-u.ac.jp \\ ${ }^{2}$ Division of Molecular Science, Graduate School of Science and Technology, Kobe University, 1-1 Rokkodai-cho, \\ Nada-ku, Kobe 657 8501, Japan \\ ${ }^{3}$ Department of Bioscience and Biotechnology, Faculty of Bioenvironmental Science, Kyoto Gakuen University, \\ 1-1 Nanjo, Sogabe, Kameoka, Kyoto 621-8555, Japan \\ ${ }^{4}$ Department of Plant Resource Science, Faculty of Agriculture, Kobe University, Nada-ku Hyogo 657-8501, Japan
}

Key words. Small GTP binding protein, Rab, Bombyx mori, PKC, PTTH

\begin{abstract}
Small GTPases of the Rab family act as essential regulators of vesicle transport pathways. Five Rab cDNA clones (BRab1, 7, 8, 11 and 14) from Bombyx mori were expressed in Escherichia coli as a thioredxin or glutathione sulfotransferase fusion protein. After purification, the fusion protein was tested for phosphorylation using protein kinase C (PKC). Results indicate that all of them were phosphorylated in vitro. The phosphorylation site of BRab1 was determined by mass-spectrometric analysis, which identified that Ser-17 of BRab1 was phosphorylated by PKC. Deletion and site-directed mutagenesis indicated that Ser-111of BRab8, in addition to Ser-17, was newly phosphorylated. Further immunohistochemical analysis using antibodies against Rab8 indicated that there are some Rab8 immunoreactive cells close to the neuropeptide secreting cells. This result suggests that in insects Rab proteins are regulated by phosphorylation and at least some of them are involved in neuropeptide secretion.
\end{abstract}

\section{INTRODUCTION}

Abbreviations used: BRab = Bombyx mori Rab; PTTH $=$ Prothoracicotropic hormone; $\mathrm{PKC}=$ protein kinase $\mathrm{C}$; -ir $=$ immunohistochemical reactivities.

The process of intracellular transport is important for almost every aspect of the functioning of cells and development of organisms. The small GTPase family of Rab proteins are essential for various aspects of membrane traffic. The Rabs are the largest subfamily of the Ras superfamily, with more than 31 members encoded by the Drosophila genome, and are localized in different subcellular compartments (Pereira-Leal \& Seabra, 2000; Pfeffer \& Aivazian, 2004; Jordens et al., 2005; Zhang et al., 2007; Ng \& Tang, 2008).

They facilitate membrane fusion by promoting the docking of transport vesicles with specific target membranes. Like other GTPases, Rab proteins cycle between active GTP-bound and inactive GDP-bound forms. In the GTP-bound active form, Rab binds with many effector proteins and carrys out a variety of cellular processes.

Rab proteins are phosphorylated in vivo and in vitro and phosphorylation alters GTP/GDP binding and cellular distribution (Chiariello et al., 1999; Fitzgerald \& Reed, 1999; Ding et al., 2003). Protein kinases, including protein kinase $\mathrm{C}(\mathrm{PKC})$, phosphorylate and thus regulate the function of Rab4 and Rab5 in insulin-responsive glucose transport (Dugani \& Klip, 2005). Activation of human platelets by thrombin results in the phosphorylation of
Rab8 (Karniguian et al., 1993), and activation of PKC alters the distribution of Rab8 (Hattula et al., 2002). Mass spectrometric analysis indicates that Rab23 in brain tissue is phosphorylated in response to cCMP (Bond et al., 2007).

Insect Rab proteins are also cellular regulators of development and cell division. Rab11 in Drosophila melanogaster is involved in the development of the nervous system, required for myoblast fusion and determines cell polarity during oogenesis (Dollar et al., 2002; Bhuin \& Roy, 2009a, b). Rab6 plays a central role in determining polarity and localization during oogenesis (Coutelis \& Ephrussi, 2007; Januschke et al., 2007). Except for Drosophila little is known about the biochemical, genetic and functional features of Rab proteins in insects. Whereas insect protein kinases are involved in learning and behaviour (Choi et al., 1991; Humphries et al., 2003) and play a role in the development of cell polarity, ecdysteroidogenesis, asymmetric cell division, neuropeptide secretion and signal transduction by diuretic peptides (Betschinger et al., 2005; Djiane et al., 2005; Tobe et al., 2005; Rybczynski \& Gilbert, 2006; Tian \& Deng, 2008). But little is known about the relationship between insect Rab proteins and phosphorylation.

In an attempt to clarify the functional roles of Rab proteins in the brain of Bombyx mori Uno et al. (2004, 2006) showed that Rab8 from Bombyx mori (BRab8) is phosphorylated in vitro by $B$. mori $\mathrm{PKC}$ expressed in mam- 
malian cells and by protein kinases purified from the brain of B. mori. We expressed Rab proteins in Escherichia coli, partially purified the encoded proteins and phosphorylated them with PKC in vitro. Mass spectrometry and mutated plasmids revealed two new phosphorylated serine residues of Rab. The functional roles of these proteins in peptide secretion were studied using antibodies against Rab8.

\section{MATERIAL AND METHODS}

\section{Material}

Thrombin, plasmid pGEX6P2, an mRNA purification kit, $\left[\gamma_{-}{ }^{32} \mathrm{P}\right]$ ATP $(>1000 \mathrm{Ci} / \mathrm{mmol})$, and glutathione-Sepharose were purchased from GE Healthcare UK Ltd (Buckinghamshire, England). PKC came from Upstate Biotechnology Inc. (NY, US), Ni-NTA Superflow resin from Qiagen (Hilden, Germany), pET32a from Novagen (Darmstad, Germany) and pCR2.2 and Pro-Q Diamond Phosphoprotein Gel Stain from Invitrogen Japan K.K (Tokyo, Japan). Peroxidase-conjugated goat antimouse IgG came from Wako Pure Chemicals (Tokyo, Japan), Taq DNA polymerase, reverse transcriptase and the DNA ligation kit from Takara Shuzo (Kyoto, Japan), Ez west blue reagents from Atto Corp (Tokyo, Japan), Artificial diet MF from Oriental Yeast Co., Ltd., (Tokyo, Japan), Bioleit mounting medium from Okenshoji Co., Ltd. (Tokyo, Japan), Aqua-Poly/Mount from Polysciences, Inc. (PA, US) and Vectastain ABC-Elite kit from Vector Laboratories (CA, US). All other chemicals were of the purest grade available.

\section{Cloning of full-length cDNA for BRabs}

BRab7 and BRab11 cDNAs were isolated from the brain of Bombyx mori. For the RT-PCR poly A RNA was directly extracted from 200 pupal brains of B. mori using a Quick Prep Micro mRNA purification kit. Single-stranded cDNA was obtained by reverse transcription using oligo $d(T)$ primer. The forward and reverse primers used in the PCR are listed in Table I. The reaction sequence was $2 \mathrm{~min}$ at $94^{\circ} \mathrm{C}, 25$ cycles of $30 \mathrm{~s}$ at $94^{\circ} \mathrm{C}, 30 \mathrm{~s}$ at $42^{\circ} \mathrm{C}, 1 \mathrm{~min}$ at $72^{\circ} \mathrm{C}$ followed by $10 \mathrm{~min}$ at $72^{\circ} \mathrm{C}$. The amplified DNA fragments of approx. $600 \mathrm{bp}$ were recovered and inserted into the pCR2.1 vector (In Vitrogen). Plasmids were sequenced using a DNA sequencer, LI-COR 4000L infrared automated sequencer (Aloka).

\section{Construction of expression plasmid and expression of cDNA for BRabs in $E$ coli}

The cDNA fragments containing the entire coding sequences of BRab7 and BRab11 were amplified using PCR and primers containing BamHI, EcoRI or XhoI (Table 1; primers 2, 3, 5 and 6). The amplified fragments were digested with BamHI, EcoRI or XhoI. The digested fragment of BRab7 was inserted into the $B a m \mathrm{HI}$ and EcoRI sites of expression vector pET28 and that of BRab11 inserted into the BamHI and XhoI sites of expression vector pET32a. This cDNA was transformed into E.coli strain BL21. Transformed $E$ coli cells (BL21) were incubated overnight in LB medium. The medium was diluted to $1: 100$ and incubated for $3 \mathrm{~h}$. The cells were collected by centrifugation at $5,000 \mathrm{~g}$ for $5 \mathrm{~min}$ and then stored at $-80^{\circ} \mathrm{C}$.

\section{Purification of BRab Protein}

All procedures were carried out at $4{ }^{\circ} \mathrm{C}$. For cells transformed with pET32a or pET28a, frozen cells from $1 \mathrm{~L}$ of culture were suspended in lysis buffer $\left(50 \mathrm{mM} \mathrm{Na}_{2} \mathrm{HPO}_{4}, 300 \mathrm{mM} \mathrm{NaCl}\right.$ and $10 \mathrm{mM}$ imidazole, $\mathrm{pH} 8.0$ ) and sonicated. The solution was cleared by centrifugation at $12000 \times \mathrm{g}$ for $40 \mathrm{~min}$. The fusion protein was then bound to $1 \mathrm{~mL}$ of Ni-NTA Superflow resin and washed with $10 \mathrm{~mL}$ of wash buffer $\left(50 \mathrm{mM} \mathrm{Na}_{2} \mathrm{HPO}_{4}, 300 \mathrm{mM}\right.$ $\mathrm{NaCl}$ and $20 \mathrm{mM}$ imidazole, $\mathrm{pH}$ 8.0). Bound proteins were eluted from the resin with $5 \mathrm{~mL}$ of elution buffer $\left(50 \mathrm{mM} \mathrm{Na}_{2} \mathrm{H}-\right.$ $\mathrm{PO}_{4}, 300 \mathrm{mM} \mathrm{NaCl}$ and $100 \mathrm{mM}$ imidazole, $\mathrm{pH}$ 8.0). Proteins were determined using BSA (Fraction V, Sigma) as the standard according to Lowry et al. (1951). BRab1, BRab8 and BRab14 proteins were expressed and purified as described before (Uno et al., 2004).

\section{SDS-PAGE}

SDS-PAGE analysis was done following the method of Laemmli (Laemmli, 1970), using a 4.5\% stacking gel and 15\% separating gel, and a constant current of $16 \mathrm{~mA}$. The proteins were visualized by staining with CBB.

\section{Protein kinase assay}

Reactions were typically carried out in a total volume of 20 $\mu \mathrm{L}$ containing $50 \mathrm{mM}$ Tris $\cdot \mathrm{HCl}(\mathrm{pH} 7.5), 6.25 \mathrm{mM} \mathrm{MgCl}_{2}$, $0.125 \mathrm{mM} \mathrm{CaCl}_{2}, 2 \mathrm{mM}$ DTT, $0.1 \mathrm{mM}$ EDTA, 0.1 or $0.5 \mu \mathrm{g}$ protein, 0.2 units of PKC, phosphatidylserine $(10 \mathrm{mg} / \mathrm{mL})$, diolein $(1 \mathrm{mg} / \mathrm{mL})$ and $10 \mu \mathrm{M}\left[\gamma^{-32} \mathrm{P}\right] \mathrm{ATP}$ or non-labelled $10 \mu \mathrm{M}$ ATP. After incubation at $30^{\circ} \mathrm{C}$ for $15 \mathrm{~min}$, the reactions were terminated by the addition of SDS-sample buffer. After samples were separated by SDS-PAGE, the gel was dried and analyzed with a BAS 1000 PhosphorImager (Fujix) or the gel was stained with Pro-Q Diamond Phosphoprotein Gel Stain according to the manufacturer's protocol and phosphorylated proteins were visualized using a Typhoon 9400 imager (GE Healthcare UK Ltd). The position of BRab8 protein on the gel was determined by staining with $\mathrm{CBB}$.

\section{Mass spectrometric analysis of phosphorylated BRab proteins}

The reaction system of $20 \mu \mathrm{L}$ contained $50 \mathrm{mM}$ Tris $\cdot \mathrm{HCl}(\mathrm{pH}$ 7.5), $6.25 \mathrm{mM} \mathrm{MgCl}_{2}, 0.125 \mathrm{mM} \mathrm{CaCl}_{2}, 2 \mathrm{mM}$ DTT, $0.1 \mathrm{mM}$ EDTA, 0.1 or $0.5 \mu \mathrm{g}$ protein, 0.2 units of PKC, phosphatidylserine $(10 \mathrm{mg} / \mathrm{mL})$, diolein $(1 \mathrm{mg} / \mathrm{mL})$ and $10 \mu \mathrm{M}$ ATP. After incubation at $30^{\circ} \mathrm{C}$ for $15 \mathrm{~min}$, SDS-sample buffer terminated the reactions. After SDS-PAGE, the gel was stained with CBB.

The gel bands were excised and digested in $50 \mathrm{mM} \mathrm{NH}_{4} \mathrm{HCO}_{3}$ with $10 \mu \mathrm{g} / \mathrm{mL}$ trypsin (Promega, Madison, WI) at $37 \mathrm{C}$ for 18 $\mathrm{h}$. After removing the supernatant, the gel pieces were extracted with $2.5 \%(\mathrm{v} / \mathrm{v})$ formic acid $/ 50 \%(\mathrm{v} / \mathrm{v}) \mathrm{ACN}$, and the extracts were then dried under vacuum. The digests were reconstituted in $0.1 \%(\mathrm{v} / \mathrm{v})$ formic acid and analyzed by a nano LC-MS/MS system coupled with a Chorus220 nano HPLC pump, an HTC-PAL autosampler (CTC Analytics AG, Zwingen, Switzerland) and a hybrid triple-quadrupole/linear ion trap tandem mass spectrometer, 4000QTRAP (Applied Biosystems, Foster City, CA). The digested peptides were separated on a $0.1 \times 50 \mathrm{~mm}$ Microm Magic C18 column (Microm BioResources Inc., Auburn, CA) equilibrated in $0.1 \%(\mathrm{v} / \mathrm{v})$ formic acid at a flow rate of $800 \mathrm{~nL} / \mathrm{min}$ and eluted with an ACN gradient from 2 to $45 \%(\mathrm{v} / \mathrm{v})$ over $30 \mathrm{~min}$. Electrospray MS was performed in Information Dependent Acquisition mode, which involves switching from MS to MS/MS mode. Local databases using the MASCOT search engine (Matrix Science, London, UK) investigated all the MS/MS spectra were searched against.

\section{Construction of deleted or mutated genes of BRab8}

The cDNA encoding an entire sequence of BRab8 obtained previously (Uno et al., 2006) was used as a PCR template. All of them were mutated Ser-132 to Ala-132. Deleted or mutated fragments (BRab8c-8f) of BRab8 were amplified by PCR using primers containing BamHI or EcoRI restriction sites (Table 1, primers 11 and 12 for BRab8c, primers 9 and 12 for BRab8d, 
TABLE 1. Primers used in the construction of BRab-expression vectors.

\begin{tabular}{|c|c|}
\hline Primers & Oligonucleotides \\
\hline $\begin{array}{l}\text { Primer } 1 \text { and } 2 \text { for RT-PCR } \\
\text { of BRab } 7 \\
\text { Primer } 3 \text { and } 4 \text { for the } \\
\text { Modification of BRab7 } \\
\text { Primer } 5 \text { and } 6 \text { for RT-PCR } \\
\text { of BRab11 } \\
\text { Primer } 7 \text { and } 8 \text { for the } \\
\text { Modification of BRab1 } 1 \\
\text { Primer } 9-13 \text { for deleted } \\
\text { BRab8 mutants }\end{array}$ & $\begin{array}{l}\text { 5'-ATGTCTTCACGGAAAAAGCTCCTGCT-3' } \\
\text { 5'-GGTCTAGCAAGCACAGTTGTCACCGTC-3' } \\
\text { 5'-GGATCCATGTCTTCACGGAAAAAGCTC-3' } \\
\text { 5'-GGAATTCGGTCTAGCAAGCACAGTTGT-3' } \\
\text { 5'-ATGGGCACAAGAGAGGATGAATATGATTA-3' } \\
\text { 5'-TCTACTGGCAGCACTGGCGCCGCACACTGT-3' } \\
\text { 5'-GGATCCATG GGCACAAGAGAGGATGAATA-3' } \\
\text { 5'-GCTCGAG TCTACTGGCAGCACTGGCGCCGC-3' } \\
\text { 5'-C } \text { GGATCCGATGCATTTAACATCTCCTTTAT -3' } \\
\text { 5'-GGAATTCTCAAAGCACGCTGCAACGCGAC -3' } \\
\text { 5'-CGGGATCCTGGGATACTGCTGGTCAAGAG -3' } \\
\text { 5'-GGAATTCATTCTCTTCAATGTTCCTAATC -3' } \\
\text { 5'-GGAATTCTCATGCTGATGTCTCCAC -3' } \\
\text { 5'-GAATTC TCACTTGTCGACCTGTCTTTGAGCATCTAA -3' } \\
\text { 5'-CTTCTAATCGGAGATCTGGGAGTGGGAAAAAC-3' } \\
\text { 5'-GTTTTTCCCACTCCCAGATCTCCGATTAGAAG-3' } \\
\text { 5'-GAAGAGGATGCCCGGGCTGATGTTGAGAAA-3' } \\
\text { 5'-TTTCTCAACATCAGCCCGGGCATCCTCTTC-3' }\end{array}$ \\
\hline
\end{tabular}

The sites of the restriction enzymes are indicated by underlining.

primers 11 and 13 for BRab8e, primers 9 and 14 for BRab8f). The amplified fragments were subcloned into pCR2.2. Sequence analysis was carried out using an ABI Prism 377 DNA sequencer. The obtained plasmids were digested with BamHI and EcoRI. Each digested fragment was then inserted into the BamHI and EcoRI sites of pET32a to encode thioredxin fusion proteins. The mutated BRab8g was produced using a Quick change site-directed mutagenesis kit (Stratagen, CA, USA). Primers 15, 16, 17 and 18 were used for BRab8g.

Sequence was determined using an ABI Prism 377. After PCR-amplification using primers 9 and 10, the amplified fragments were subcloned into pCR2.2 in order to construct BRab8b. After sequencing, the plasmids were digested with $B a m \mathrm{HI}$ and EcoRI. Each digest was then inserted into the BamHI and EcoRI sites of pET32a. BRab8b was obtained by cutting the plasmid with $N s i$ I and self-ligating. BRab8a was constructed by cutting BRab8 with Nsi I and self-ligating. These plasmids were used to transform E. coli strain Rosetta. Cells transformed with pET32a were incubated at $37^{\circ} \mathrm{C}$ for 3 to $4 \mathrm{~h}$ in LB (Luria-Bertani) medium until the O.D. at $600 \mathrm{~nm}$ reached 0.6. The thioredxin fusion protein was produced by adjusting the culture to $1 \mathrm{mM}$ isopropyl $\beta$-D-thiogalactopyranoside and incubating for $3 \mathrm{~h}$ at $37^{\circ} \mathrm{C}$. The cells expressing the recombinant fusion proteins were collected by centrifugation for $10 \mathrm{~min}$ at $5000 \times g$ and then stored at $-80^{\circ} \mathrm{C}$.

\section{Western blotting}

Proteins were separated by SDS-PAGE and electrophoretically transferred to a nitrocellulose membrane. The membrane was blocked in Blocking One solution (Nakalai Tesque, Kyoto, Japan). Next, the blot was incubated in 1:2000 anti-BRab8 (Uno et al., 2007) serum in TBS (50 mM Tris· $\mathrm{HCl}, \mathrm{pH} 8.0$, and $50 \mathrm{mM} \mathrm{NaCl}$ ) containing Blocking One. The membrane was washed three times with TBS containing $0.05 \%$ Tween- $20(\mathrm{v} / \mathrm{v})$. Next, the blot was incubated with 1 : 2000 peroxidaseconjugated goat anti-mouse IgG. After washing three times with TBS containing Tween-20, protein was detected using Ez west blue reagents.

\section{Immunohistochemistry}

Brains were dissected out as above and fixed for $24 \mathrm{~h}$ in Bouin's or alcoholic Bouin's fixative at $4^{\circ} \mathrm{C}$. Standard histochemical methods were used to dehydrate, embed in paraplast, section $(12 \mu \mathrm{m})$, deparaffinize and rehydrate tissues. Following washing in distilled water and Tris-buffered saline (TBS; 135 $\mathrm{mM} \mathrm{NaCl}, 2.6 \mathrm{mM} \mathrm{KCl}, 25 \mathrm{mM}$ Tris-HCl, pH7.6) containing $0.1 \%$ Tween 20 (TBS-Tw) at room temperature (RT), the sections were blocked with antibody dilution buffer (TBS-Tw containing $1 \%$ of BSA) for $30 \mathrm{~min}$ at RT. Sections were incubated with a primary antibody in a humidified chamber overnight at $4^{\circ} \mathrm{C}$. Next, the sections were rinsed $(3$ times for $5 \mathrm{~min}$ with TBS-Tw at RT) and then incubated with $7.5 \mu \mathrm{g} / \mathrm{ml}$ of secondary antibody. After washing as above, bound antibody was labelled with alkaline phosphatase using a Vectastain ABC kit. The enzymatic activity was detected with $\mathrm{DAB}$ and the reaction was stopped in distilled water. Stained sections were dehydrated and mounted in Bioleit mounting medium. The slides were examined under a DX50 microscope and photographed with a CCD camera, and for detecting Vector Red fluorescence a WIG mirror/filter unit was used.

\section{RESULTS}

\section{Phosphorylation of BRab proteins}

Serine, threonine and tyrosine residues are phosphorylated in vivo and in vitro in mammalian Rab proteins (Chiariello et al., 1999; Fitzgerald \& Reed, 1999; Ding et al., 2003). To examine if insect Rab proteins are also phosphorylated by PKC, cDNAs of Rabs from B. mori (BRab1, BRab7, BRab11 and BRab14) were isolated and inserted into an expression vector. The expressed proteins were partially purified, phosphorylated with $\mathrm{PKC}$ in vitro and phosphorylated proteins were detected using Pro-Q Diamond gel stain (Fig. 1). The result showed that four BRabs were phosphorylated in vitro by PKC.

\section{Mass spectral analysis of BRab1 protein}

As described above, four Rab proteins were phosphorylated by PKC. To identify phosphorylated amino acid residues of BRabs, a mass spectrometric analysis of BRabs was conducted (Fig. 2). As a result, one serine residue of BRab1 (Ser-17) was identified. The phosphorylated amino acids of the other three BRab proteins 


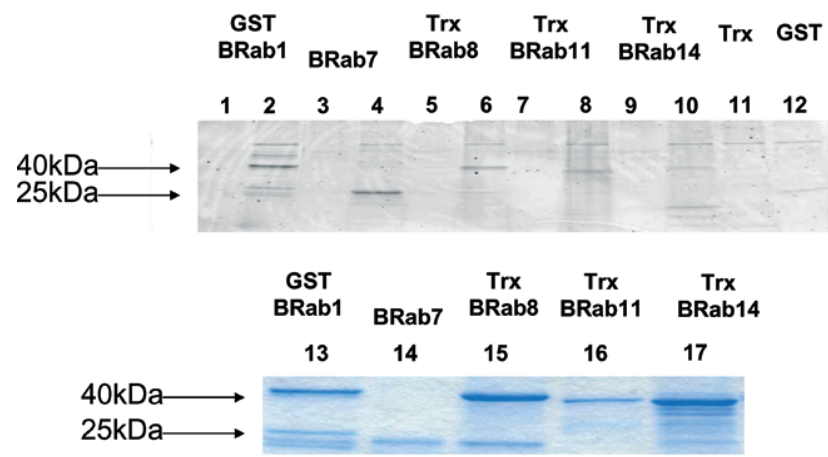

Fig. 1. Phosphorylation of BRab1, BRab7, BRab10, BRab11 and BRab14 by PKC in vitro. Top: The cDNAs encoding the rabs were expressed as fusion proteins. After purification, PKC and ATP were incubated with BRab1 (lane 2), BRab7 (lane 4), BRab10 (lane 6), BRab11 (lane 8), BRab14 (lane10), thioredxin (Trx; lane11) or GST (lane 12). Controls (lanes 1, 3, 5, 7, 9 and 11) did not contain PKC. The reactions were terminated with SDS-sample buffer, separated using SDS-PAGE and detected using Pro-Q Diamond gel stain. Bottom: Rab proteins (lane 13 $-17)$ were stained with CBB.

(BRab1, 7 and 14) could not be identified by MS analysis.

\section{Phosphorylation of fragments of BRab8}

Ser-132 of BRab8 is phosphorylated by PKC (Uno et al., 2007). However, phosphorylatd amino acid residues of BRab8 were not identified by the MS analysis (data

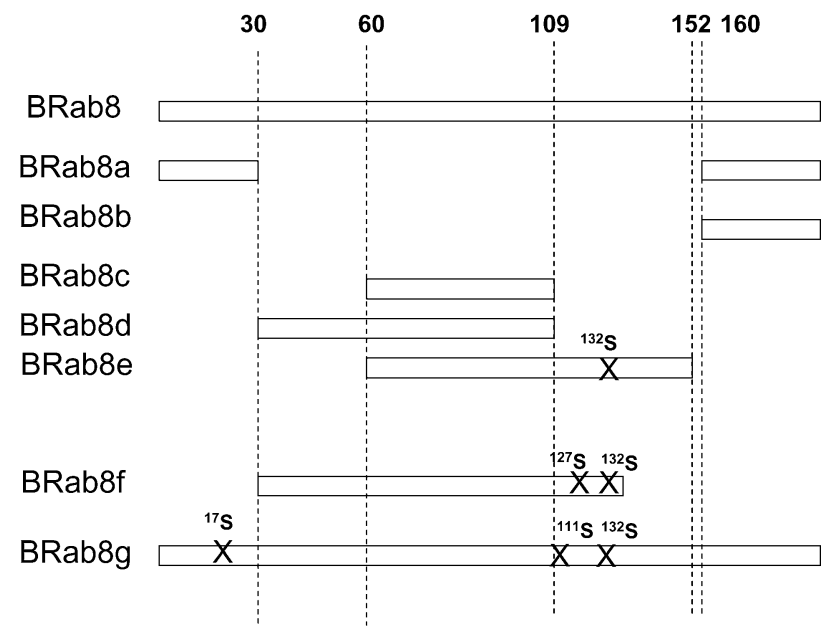

Fig. 3. Construction of deletion or site-directed mutants of BRab8. Mutants were generated by PCR using the full-length cDNA as a template. The serine and threonine residues that are candidate PKC phosphorylation sites are indicated. $\mathrm{X}$ is the mutated position.

not shown). In this study we tried to identify the phosphorylated amino acids of BRab8 other than Ser-132. At first Ser-132 of BRab8 was replaced by Ala. Using PCR with this mutated cDNA as a template, we constructed cDNAs for five deletion mutants (Fig. 3 BRab8a-e), expressed them as thioredxin fusion proteins, purified them and phosphorylated them with PKC (Fig. 4). Two of the five

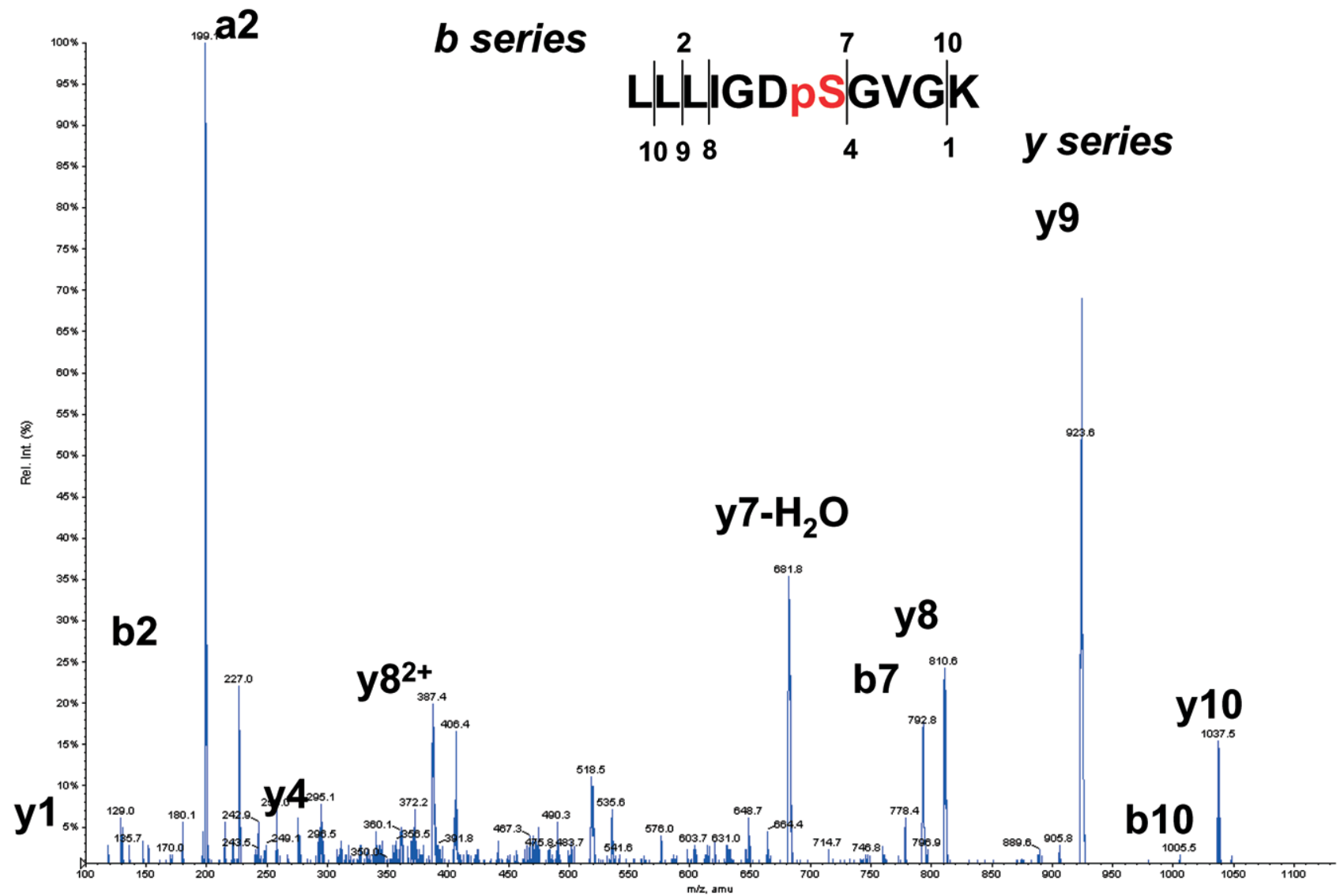

Fig. 2. The determination of the phosphorylated residue of rab1 using mass spectral analysis. 

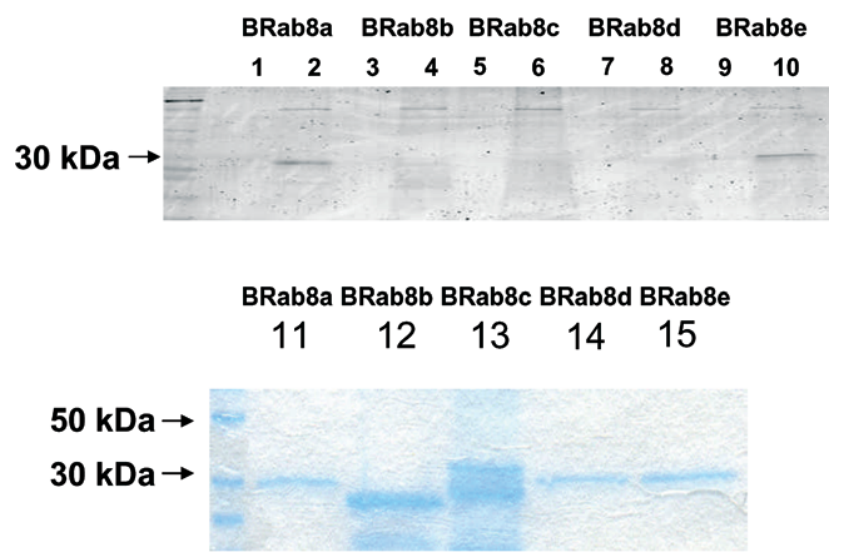

Fig. 4. Phosphorylation of deleted proteins of BRab8. The cDNAs encoding these mutants were inserted into pET32a to produce thioredxin fusion proteins. After expression and purification PKC and ATP were incubated with BRab8a (lane 2), BRab8b (lane 4), BRab8c (lane 6), BRab8d (lane 8) or BRab8e (lane 10). Controls (lanes 1, 3, 5, 7 and 9) did not contain PKC. The reactions were terminated using SDS-sample buffer and separated by SDS-PAGE. Gels were analyzed using a PhosphorImager. Rab proteins (lane11-15) were stained with CBB.

proteins, BRab8a and BRab8e, were phosphorylated, but BRab8b, BRab8c and BRab8d were not. These results indicate that serine or threonine-containing regions of amino acid residues 1-30 and 109-152 may be phosphorylated by $\mathrm{PKC}$ in vitro.

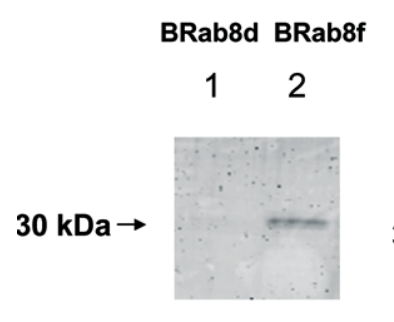

BRab8d BRab8f

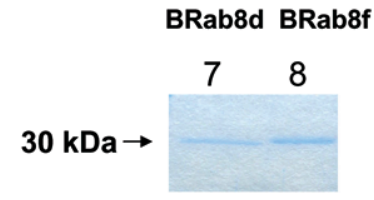

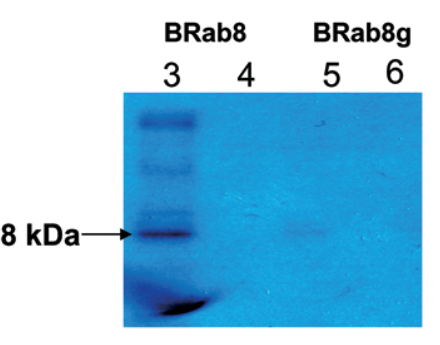

BRab8 BRab8g

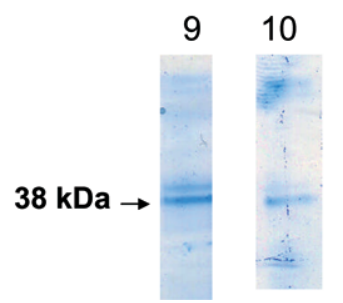

Fig. 5. Phosphorylation of site-directed mutants of BRab8. The cDNAs encoding these mutants were inserted into pET32a to produce thioredxin fusion proteins. After expression and purification PKC and $\left[\gamma^{32} \mathrm{P}\right] \mathrm{ATP}$ or ATP were incubated with BRab8d (lane 1), BRab8f (lane 2), BRab8 (lane 3) or BRab8g (lane 5). Controls (lanes 4 and 6) did not contain PKC. The reactions were terminated using SDS-sample buffer and separated by SDS-PAGE. Gels were analyzed using a PhosphorImager or in the case of $\left[\gamma_{-}{ }^{32} \mathrm{P}\right]$ ATP the gel was dried and analyzed using a BAS 1000 PhosphorImager. Rab proteins (lane 7-10) were stained with CBB.

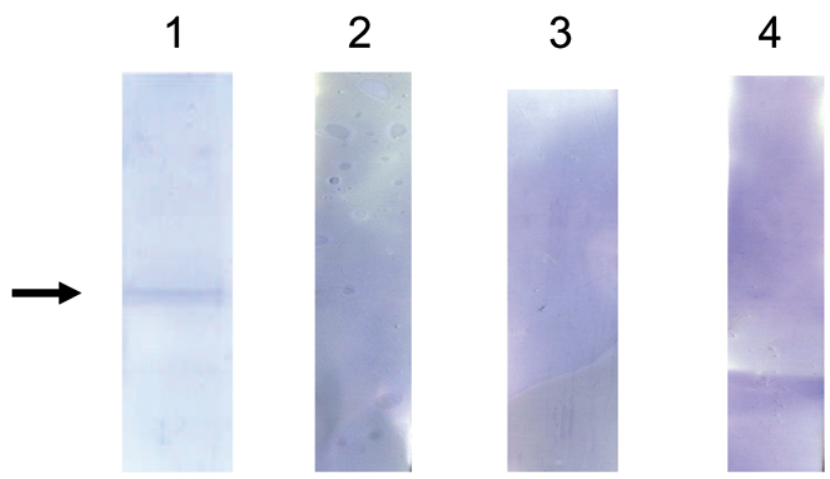

Fig. 6. Immunoblotting analysis of BRab8 expression in the brain of B. mori. Brains from B. mori were homogenized in 50 $\mathrm{mM}$ HEPES-HCl (pH 7.5) containing 20\% glycerol, $1 \mathrm{mM}$ EDTA and $1 \mathrm{mM}$ dithiothreitol. Proteins $(1 \mu \mathrm{g})$ were transferred to a nitrocellulose membrane after electrophoresis. The membrane was incubated with antibody (lane 1). Lane 2, control (mouse antiserum was used as primary antibody); lane 3, control (antibody adding antigen was used as primary antibody). Lane 4, control (no primary antibody was used). The arrows indicate Rab8 proteins.

\section{Identification of the site phosphorylated on BRab8}

To identify the phosphorylated amino acid of BRab8, we generated two deletion mutants (Fig. 3; BRab8f and $\mathrm{g}$ ), expressed them as thioredxin fusion proteins, purified them and phosphorylated them with PKC (Fig. 5). BRab8f was phosphorylated, but BRab8g was not phosphorylated. The result indicates that, two amino acid residues (Ser-17 and Ser-111) were phosphorylated in vitro.

\section{Western blotting}

To investigate the functional roles of Rab8 we employed immunohistochemistry to localize Rab8-ir in the brain of B. mori. First, we carried out Western blotting using an antiserum to BRab8. The brain homogenate from B. mori was subjected to electrophoreses and immunoblotted with the antibody. Immunoblots revealed one band (Fig. 6, lane 1), with none in the control (lanes $2-4)$. These results validated the use of the antiserum to BRab8 to search for Rab8 in the brain of B. mori.

\section{Immunohistochemistry in the brain of Bombyx mori}

We detected Rab8-like immunohistochemical reactions (BRab8-ir) in the brain of Bombyx mori (Fig. 7). Rab8-ir was observed only in certain areas of the brain (arrows in Fig. 7A and B). These immunoreactive cells were near to cells that show an immunoreaction to PTTH or bombyxin (Mizoguchi et al., 1987; Kawakami et al., 1990; Ishizaki \& Suzuki, 1994; Dai et al., 1995). These results indicate that Rab8 was present in specific cells of the brain of $B$. mori.

\section{DISCUSSION}

$\mathrm{PKC}$ is a serine/threonine protein kinase that regulates signal transduction, cell growth, transformation and gene expression (Nishizuka, 1995). PKC of Bombyx mori has recently been shown to phosphorylate BRab8 in vitro (Uno et al., 2004, 2006). In addition, one serine residue, 

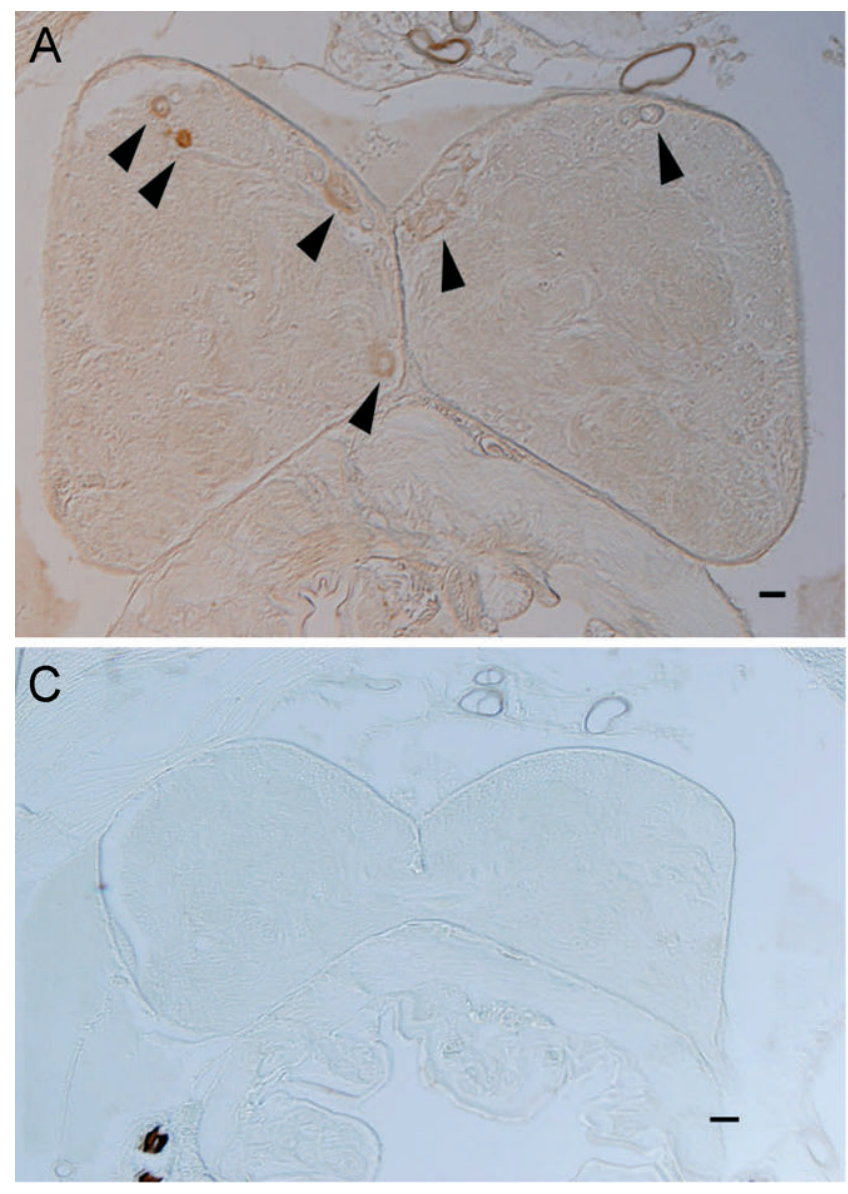

Ser-132, is also phosphorylated by PKC in vitro (Uno et al., 2007). The present study showed that BRab1, BRab7, BRab10 and BRab11, in addition to BRab8, were phosphorylated by PKC in vitro (Fig. 1). Previously Rab1 protein was not phosphorylated when $\left[\gamma-{ }^{32} \mathrm{P}\right]$ ATP was used as a substrate (Uno et al., 2004). In this study Pro-Q Diamond Phosphoprotein Gel Stain was used to detect phosphorylated proteins. This stain detected phosphorylated Rab1 proteins.

MS analysis indicates that Ser-17 of Rab1 is phosphorylated in vitro (Fig. 2). Database and crystallographic analysis indicate that Ser-17 is located between $\beta$-sheet 1 and an $\alpha$-helix 1 and this region contains Ser-17, a conserved nucleotide binding motif (Pereira-Leal \& Seabra, 2000). This suggests that phosphorylated Ser-17 changes the affinity of Rab proteins for GDP/GTP binding of Rab proteins.

Rab8 has diverse functions, including the regulation of synaptic plasticity, neurite outgrowth, apical protein localization in intestinal cells and melanosome transport (Huber et al., 1993, 1995; Gerges et al., 2004; Chabrillat et al., 2005; Sato et al., 2007; Ng \& Tang, 2008). In addition, Rab8 is implicated in both Huntington's (Sahlender et al., 2005) and Alzheimer's disease (Kametani et al., 2004).

In addition to Ser-132 there are two other serine residues (Ser-17 and Ser-111) of BRab8 that are phosphorylated by $\mathrm{PKC}$ in vitro (Figs 4 and 5). Crystallographic studies of Rab8 indicate that Ser-111 is located on the

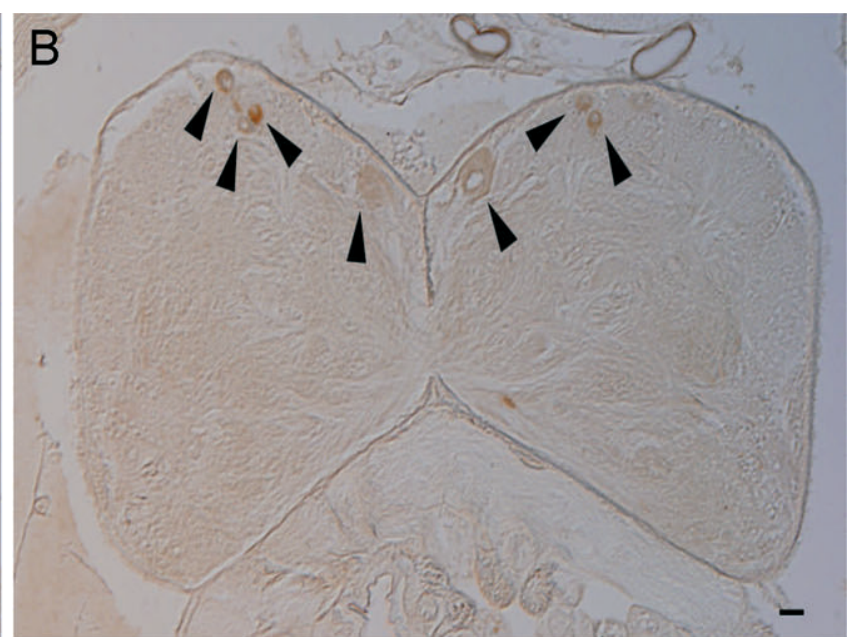

Fig. 7. Rab8 immunoreactivity in the brain of Bombyx mori. Rab8-like immunoreactive cells in the brain of Bombyx mori (A, B). Arrows indicate Rab8-ir cells. Control (C). Scale bar indicates $100 \mu \mathrm{m}$.

surface of BRab8 between $\beta$-sheet 5 and $\alpha$-helix 3 and this region containing Ser-111 is a subfamily with specific sequences (Pereira-Leal \& Seabra, 2000; Itzen et al., 2006). These regions show a higher identity within the sub-families than the overall sequence.

Rab proteins interact with various effector proteins (Spang, 2004; Ali \& Seabra, 2005; Grosshans et al., 2006). For example, by using two-hybrid screening optineurin, MSS4 and Rabin8 were identified as Rab8associated proteins (Burton et al., 1994; Hattula et al., 2002; Sahlender et al., 2005). The region containing Ser-111 may be related to binding Rab8-specific effector. Phosphorylation of Rab8 may change its interaction with these effector proteins. Far-Western blotting and GST pull-down experiments must be performed to determine whether this occurs and with which binding proteins it interacts.

To clarify the possible role of Rab8 protein in the neurosecretion of insects immunohistochemistry using an antibody against BRab8 was used. Firstly, immunoblotting indicates that BRab 8 was present in the brain of Bombyx mori (Fig. 6). BRab8 was present only in a particular area of the brain of Bombyx mori (Fig. 7). Bombyxin is a neuropeptide hormone similar to mammalian insulin. PTTH (Prothoracicotropic hormone) is a hormone that stimulates ecdysone synthesis and secretion (Mizoguchi et al., 1987; Kawakami et al., 1990; Ishizaki \& Suzuki, 1994). However, although the biochemistry is well understood the mechanism by which PTTH and 
Bombyxin pass from the brain into the hemolymph is poorly understood. The immunoreactive cells are situated close to the neuropeptide-secreting cells, which may indicate that Rab8 proteins are neuropeptides. Further study is required in which double-staining, using antibodies against both Rab8 and neuropeptides (bombyxin or PTTH), is used.

We have shown that two serine residues (Ser-17 and Ser-111) of BRab8 were phosphorylated by PKC in vitro (Figs 4 and 5), which could modify the affinities of these regulatory proteins and lead to functional changes in BRab8. Furthermore, we have shown that Rab8-ir is present in the brain of Bombyx mori. Although the phosphorylation of $\mathrm{Rab}$ is poorly understood our finding strongly suggest that one functional role of this phosphorylation in insects is in the secretion of neuropeptides.

ACKNOWLEDGEMENT. This work was funded in part by a Grant-in-Aid for Scientific Research (C), 20580053, from the Japan Society for the Promotion of Science.

\section{REFERENCES}

Ali B.R. \& SEabra M.C. 2005: Targeting of Rab GTPases to cellular membranes. Biochem. Soc. Trans. 33: 652-656.

Betschinger J., Eisenhaber F. \& KNoblich J.A. 2005: Phosphorylation-induced autoinhibition regulates the cytoskeletal protein Lethal (2) giant larvae. Curr. Biol. 15: 276-282.

BhuIN T. \& Roy J.K. 2009a: Rab11 is required for embryonic nervous system development in Drosophila. Cell Tissue Res. 335: 349-356.

BHUIN T. \& Roy J.K. 2009b: Rab11 is required for myoblast fusion in Drosophila. Cell Tissue Res. 336: 489-499.

Bond A.E., Dudley E., Tuytten R., Lemiere F., Smith C.J., EsMans E.L. \& Newton R.P. 2007: Mass spectrometric identification of Rab23 phosphorylation as a response to challenge by cytidine $3^{\prime}, 5^{\prime}$-cyclic monophosphate in mouse brain. Rapid Commun. Mass. Spectrom. 21: 2685-2692.

Burton J.L., Burns M.E., Gatti E., Augustine G.J. \& De CAmilli P. 1994: Specific interactions of Mss4 with members of the Rab GTPase subfamily. EMBO J. 13: 5547-5558.

Chabrillat M.L., Wilhelm C., Wasmeier C., Sviderskaya E.V., LOUVARD D. \& COUDRIER E. 2005: Rab8 regulates the actinbased movement of melanosomes. Mol. Biol. Cell 16: $1640-1650$.

Chiariello M., Bruni C.B. \& Bucci C. 1999: The small GTPases Rab5a, Rab5b and Rab5c are differentially phosphorylated in vitro. FEBS Lett. 453: 20-24.

Choi K.W., Smith R.F., Buratowski R.M. \& Quinn W.G. 1991: Deficient protein kinase $\mathrm{C}$ activity in turnip, a Drosophila learning mutant. J. Biol. Chem. 266: 15999-15606.

Coutelis J.B. \& EpHrussi A. 2007: Rab6 mediates membrane organization and determinant localization during Drosophila oogenesis. Development 134: 1419-1430.

Dai J.L., Mizoguchi A., Satake S., Ishizaki H. \& Gilbert L.I. 1995: Developmental changes in the prothoracicotropic hormone content of the Bombyx mori brain-retrocerebral complex and hemolymph: analysis by immunogold electron microscopy, quantitative image analysis, and time-resolved fluoroimmunoassay. Dev. Biol. 171: 212-223.

Ding J., Soule G., Overmeyer J.H. \& Maltese W.A. 2003: Tyrosine phosphorylation of the Rab24 GTPase in cultured mammalian cells. Biochem. Biophys. Res. Commun. 312: $670-675$.
Ditane A., Yogev S. \& MlodziK M. 2005: The apical determinants aPKC and dPatj regulate Frizzled-dependent planar cell polarity in the Drosophila eye. Cell 121: 621-631.

Dollar G., Struckhoff E., Michaud J. \& Cohen R.S. 2002: Rab11 polarization of the Drosophila oocyte: a novel link between membrane trafficking, microtubule organization, and oskar mRNA localization and translation. Development 129: $517-526$.

Dugani C.B. \& Klip A. 2005: Glucose transporter 4: cycling, compartments and controversies. EMBO Rep. 6: 1137-1142.

FitzGerald M.L. \& Reed G.L. 1999: Rab6 is phosphorylated in thrombin-activated platelets by a protein kinase $\mathrm{C}$-dependent mechanism: effects on GTP/GDP binding and cellular distribution. Biochem. J. 342: 353-360.

Gerges N.Z., Backos D.S. \& Esteban J.A. 2004: Local control of AMPA receptor trafficking at the postsynaptic terminal by a small GTPase of the Rab family. J. Biol. Chem. 279: 43870-43878.

Grosshans B.L., Ortiz D. \& Novick P. 2006: Rabs and their effectors: achieving specificity in membrane traffic. Proc. Natl. Acad. Sci. USA 103: 11821-11827.

Hattula K., Furuhjelm J., Arffman A. \& Peranen J. 2002: A Rab8-specific GDP/GTP exchange factor is involved in actin remodeling and polarized membrane transport. Mol. Biol. Cell 13: $3268-3280$.

Huber L.A., de Hoop M.J., Dupree P., Zerial M., Simons K. \& Dотті C. 1993: Protein transport to the dendritic plasma membrane of cultured neurons is regulated by rab8p. J. Cell Biol. 123: 47-55.

Huber L.A., Dupree P. \& Dotti C.G. 1995: A deficiency of the small GTPase rab8 inhibits membrane traffic in developing neurons. Mol. Cell Biol. 15: 918-924.

Humphries M.A., Muller U., Fondrk M.K. \& Page R.E., JR. 2003: PKA and PKC content in the honey bee central brain differs in genotypic strains with distinct foraging behavior. $J$. Comp. Physiol. (A) 189: 555-562.

IsHIZAKI H. \& SUzUKI A. 1994: The brain secretory peptides that control moulting and metamorphosis of the silkmoth, Bombyx mori. Int. J. Dev. Biol. 38: 301-310.

Itzen A., Pylypenko O., Goody R.S., Alexandrov K. \& Rak A. 2006: Nucleotide exchange via local protein unfoldingstructure of Rab8 in complex with MSS4. EMBO J. 25: $1445-1455$.

Januschke J., Nicolas E., Compagnon J., Formstecher E., Goud B. \& Guichet A. 2007: Rab6 and the secretory pathway affect oocyte polarity in Drosophila. Development 134: 3419-3425.

Jordens I., Marsman M., KuiJl C. \& Neefjes J. 2005: Rab proteins, connecting transport and vesicle fusion. Traffic $\mathbf{6}$ : 1070-1077.

Kametani F., Usami M., Tanaka K., Kume H. \& Mori H. 2004: Mutant presenilin (A260V) affects Rab8 in PC12D cell. Neurochem. Int. 44: 313-320.

Karniguian A., Zahraoul A. \& TAVItian A. 1993: Identification of small GTP-binding rab proteins in human platelets: thrombin-induced phosphorylation of rab3B, rab6, and rab8 proteins. Proc. Natl. Acad. Sci. USA 90: 7647-7651.

Kawakami A., Kataoka H., OKa T., Mizoguchi A., KimuraKawakami M., Adachi T., Iwami M., Nagasawa H., Suzuki A. \& IsHizAKi H. 1990: Molecular cloning of the Bombyx mori prothoracicotropic hormone. Science 247: 1333-1335.

LAEMMLI U.K. 1970: Cleavage of structural proteins during the assembly of the head of bacteriophage T4. Nature 227: $680-685$. 
Lowry O.H., Rosebrough N.J., Farr A.L. \& Randall R.J. 1951: Protein measurement with the Folin phenol reagent. $J$. Biol. Chem. 193: 265-275.

Mizoguchi A., Ishizaki H., Nagasawa H., Kataoka H., Isogai A., Tamura S., Suzuki A., Fujino M. \& Kitada C. 1987: A monoclonal antibody against a synthetic fragment of bombyxin (4K-prothoracicotropic hormone) from the silkmoth, Bombyx mori: characterization and immunohistochemistry. Mol. Cell Endocrinol. 51: 227-235.

NG E.L. \& TANG B.L. 2008: Rab GTPases and their roles in brain neurons and glia. Brain Res. Rev. 58: 236-246.

NishizuKA Y. 1995: Protein kinase $C$ and lipid signaling for sustained cellular responses. FASEB J. 9: 484-496.

Pereira-Leal J.B. \& Seabra M.C. 2000: The mammalian Rab family of small GTPases: definition of family and subfamily sequence motifs suggests a mechanism for functional specificity in the Ras superfamily. J. Mol. Biol. 301: 1077-1087.

Pfeffer S. \& Aivazian D. 2004: Targeting Rab GTPases to distinct membrane compartments. Nat. Rev. Mol. Cell Biol. 5: 886-896.

RybCZynski R. \& GiLbert L.I. 2006: Protein kinase C modulates ecdysteroidogenesis in the prothoracic gland of the tobacco hornworm, Manduca sexta. Mol. Cell Endocrinol. 251: $78-87$.

Sahlender D.A., Roberts R.C., Arden S.D., Spudich G., TAYlor M.J., Luzio J.P., Kendrick-Jones J. \& Buss F. 2005: Optineurin links myosin VI to the Golgi complex and is involved in Golgi organization and exocytosis. J. Cell Biol. 169: 285-295.
Sato T., Mushiake S., Kato Y., Sato K., Sato M., Takeda N., Ozono K., Miki K., Kubo Y., Tsuji A., Harada R. \& Harada A. 2007: The Rab8 GTPase regulates apical protein localization in intestinal cells. Nature 448: 366-369.

SpANG A. 2004: Vesicle transport: a close collaboration of Rabs and effectors. Curr. Biol. 14: R33-34.

Tian A.G. \& Deng W.M. 2008: Lgl and its phosphorylation by aPKC regulate oocyte polarity formation in Drosophila. Development 135: 463-471.

Tobe S.S., Zhang J.R., Schooley D.A. \& Coast G.M. 2005: A study of signal transduction for the two diuretic peptides of Diploptera punctata. Peptides 26: 89-98.

Uno T., Nakao A. \& Katsurauma C. 2004: Phosphorylation of Rab proteins from the brain of Bombyx mori. Arch. Insect Biochem. Physiol. 57: 68-77.

Uno T., Nakao A., Fujiwara Y., Katsurauma C., Nakada T. \& Iтон O. 2006: Molecular cloning and expression of protein kinase C from Bombyx mori. Arch. Insect Biochem. Physiol. 61: $65-76$

Uno T., Nakada T., Okamaoto S., Nakamura M., Matsubara M., Imaishi H., Yamagata H., Kanamaru K. \& TaKagi M. 2007: Determination of phosphorylated amino acid residues of Rab8 from Bombyx mori. Arch. Insect Biochem. Physiol. 66: 89-97.

Zhang J., Schulze K.L., Hiesinger P.R., Suyama K., Wang S., Fish M., Acar M., Hoskins R.A., Bellen H.J. \& Scott M.P. 2007: Thirty-one flavors of Drosophila rab proteins. Genetics 176: $1307-1322$.

Received February 10, 2009; revised and accepted June 15, 2009 